\title{
ANALYSIS OF TRADE EFFICIENCY IN SERBIA BASED ON THE PROMETHEE METHOD
}

\author{
Lukic RADOJKO \\ Faculty of Economics, University of Belgrade \\ radojko.lukic@ekof.bg.ac.rs
}

\begin{abstract}
Various methods of multi-criteria optimization have been developed and have recently been widely applied in trade. With this in mind, this paper investigates the efficiency of trade in Serbia based on the Promethee method. Using this method, in relation to the analysis of the analysis, we can more accurately assess the efficiency of trade in Serbia in the function of improvement in the future by taking appropriate more efficient measures. The results of research obtained using the Promethee method show that the efficiency of trade in Serbia has been continuously increasing recently. It was the best in 2020. It was positively influenced by numerous macro and micro factors, such as: favorable economic climate, low inflation, lower interest rates, foreign retail chains, increased employment, increased living standards, stable exchange rate, digitalization of the entire business, etc. The impact of the Covid-19 coronary virus pandemic on trade efficiency in Serbia is negligible. It is, among other things, largely neutralized with the increase in electronic sales. This is the case in other countries as well (as evidenced by the recently published available empirical data of Eurostat for European Union distribution trade). Empirical research shows that this is not, however, the case with other sectors in Serbia, such as transport and storage, tourism and catering, banks, etc. To increase (or maintain the existing) efficiency of trade in Serbia in the future, it is necessary to improve the efficiency of management of human resources, assets, capital, sales and profits. The main problem is that there are no similar empirical studies of trade efficiency in other countries, which limits international comparison. This paper can therefore serve as an impetus for future similar empirical research.
\end{abstract}

Keywords: efficiency, factors, Promethee methods, Serbian trade.

DOI: https://doi.org/10.24818/beman/2021.11.4-02

\section{INTRODUCTION}

The issue of measuring the efficiency of trade companies is continuously topical, complex and very important. For these reasons, it is permanently researched on a global level, by individual countries and individual trade companies. At the same time, different, individually or integrated, methods of mathematical programming (multi-criteria decision-making) are increasingly used. This includes the Promethee method. Starting from that, the subject of research in this paper is the assessment of the efficiency of trade companies in Serbia on the basis of the Promethee method. The purpose and goal of this is to fully understand the current situation and propose adequate measures to improve the efficiency of trade in Serbia in the future. This, among other things, reflects the scientific and professional contribution of this paper. 
A brief review of the literature could be presented as follows:

1. Recently, different or individually different methods of multi-criteria decision-making are used in the literature to measure the efficiency of all companies, which means trade (AHP, TOPSIS, POMETHEE, VASPAS, and others) (Bölükbaş, 2012; Ersoy, 2017; Kaushik, 2020; KITA, 2017; Gaur, 2020; Okwu, 2020; Pachar, 2021; Singh, 2020). Because they give more precise results in relation to the ratio analysis. 2. Recently, in Serbia, following the example of the world, various methods of multi-criteria decisionmaking have been increasingly used to measure the efficiency of all companies, including trade ones (Lukic, 20019, 2020a,b,c, 2021a,b,c).

3. But, regardless of that, in the literature in Serbia, as far as we know, there is still no complete work dedicated to the analysis of trade efficiency in Serbia on the basis of the Promethee method, this gap should be filled to some extent by this work. his scientific and professional contribution.

The starting hypothesis of the research in this paper is that continuous monitoring of the factors of the dynamics of efficiency of trade companies in all countries, which means in Serbia, is a key prerequisite for its improvement in the future. This provides a basis for timely action in that direction by taking appropriate measures and more efficient control of their implementation.

The research methodology of the given hypothesis is based on the application of the Promethee method. This method, considering that it enables the perception of the real situation, has a significant role in improving the efficiency of trade companies in Serbia. It makes it easier to see which is the most favorable alternative to the given criteria in specific circumstances and restrictions, and what measures should be taken to increase the efficiency of trade measures in Serbia in the future. Compared to ratio analysis, the Promethee method gives more accurate results. In addition, special software has been developed for its easier application in practice. For these reasons, it is recommended, especially in combination with other methods of multi-criteria decision-making.

Empirical data for the needs of research on the issues treated in this paper were obtained from the Business Registers Agency of the Republic of Serbia. In methodological terms, they are "produced" in accordance with relevant international standards and, given that, there are no restrictions on the international comparability of initial data and results. The research covers the period 2013-2020 due to the fact that empirical data are available for this period to measure the efficiency of trade in Serbia.

The treatment of the treated problem in this paper is designed so that in addition to the introduction and conclusion, it includes the basic characteristics of the Promethee method and the problems and importance of measuring the efficiency of trade in Serbia using the Promethee method. 


\section{PROMETHEE METOHOD}

The Promethee method was developed by Brans (1982), Promethe I for partial ranking, and Promethee II for full ranking of alternatives (Brans, 1982). The Promethee II method is based on comparing pairs of alternatives for each criterion. Alternatives are evaluated according to different criteria that need to be maximized or minimized (Vujosevic, 2016). The Promethee method is widely used because it has a different way of structuring problems compared to other methods; it enables the processing of a large amount of data and quantifies qualitative quantities (Macharis et al., 2004); and there are appropriate software (Decision Lab) that support this method.

The application of the Promethee II method requires that two additional types of information be available (Behzadian, 2010).

1. Information on the relative importance (i.e. weights) of the considered criteria. The Promethee II method assumes that the decision maker can appropriately determine the weight of each criterion analyzed, especially when the number of criteria is not too large (Macharis, 2004).

2. Information on the function of preferences, which the decision maker uses when comparing the contribution of the observed alternatives in terms of each specific criterion. In order to facilitate the selection of a particular preference function, Brans and Vincke (Brans, 1985) proposed six types of criteria: 1 - Usal Criterion, 2 - U-shape Criterion, 3 - V-shaped Criterion, 4 - Level Criterion , 5 - V-shaped with Indifference Criterion and 6 - Gaussian Criterion, which is easy to define. For each criterion, the value of the threshold of indifference $(q)$, the threshold of strict preferences $(p)$, and the mean value between $p$ and $q(d)$ should be determined (Brans, 1986). Table 1 shows the types of generated criteria.

TABLE 1. TYPES OF GENERATED CRITERIA

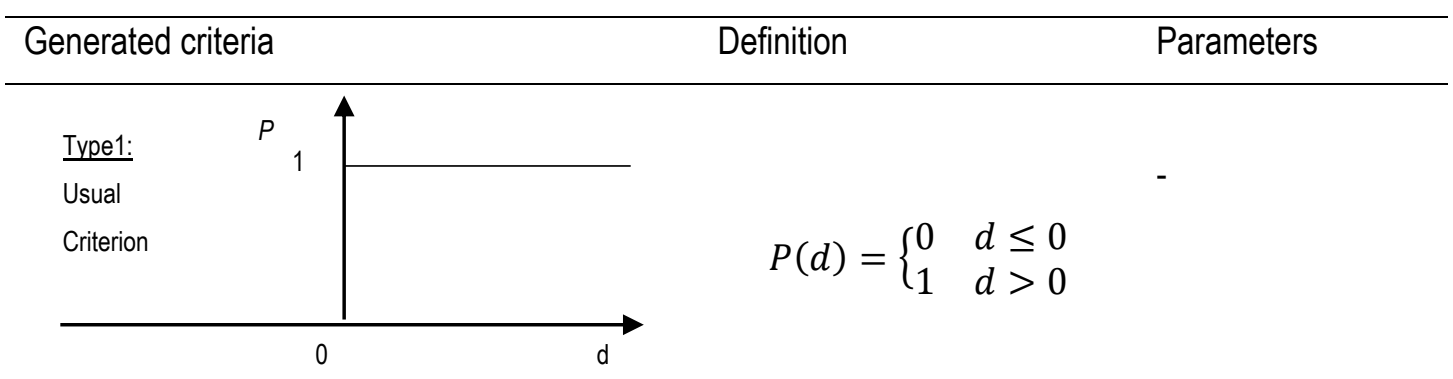



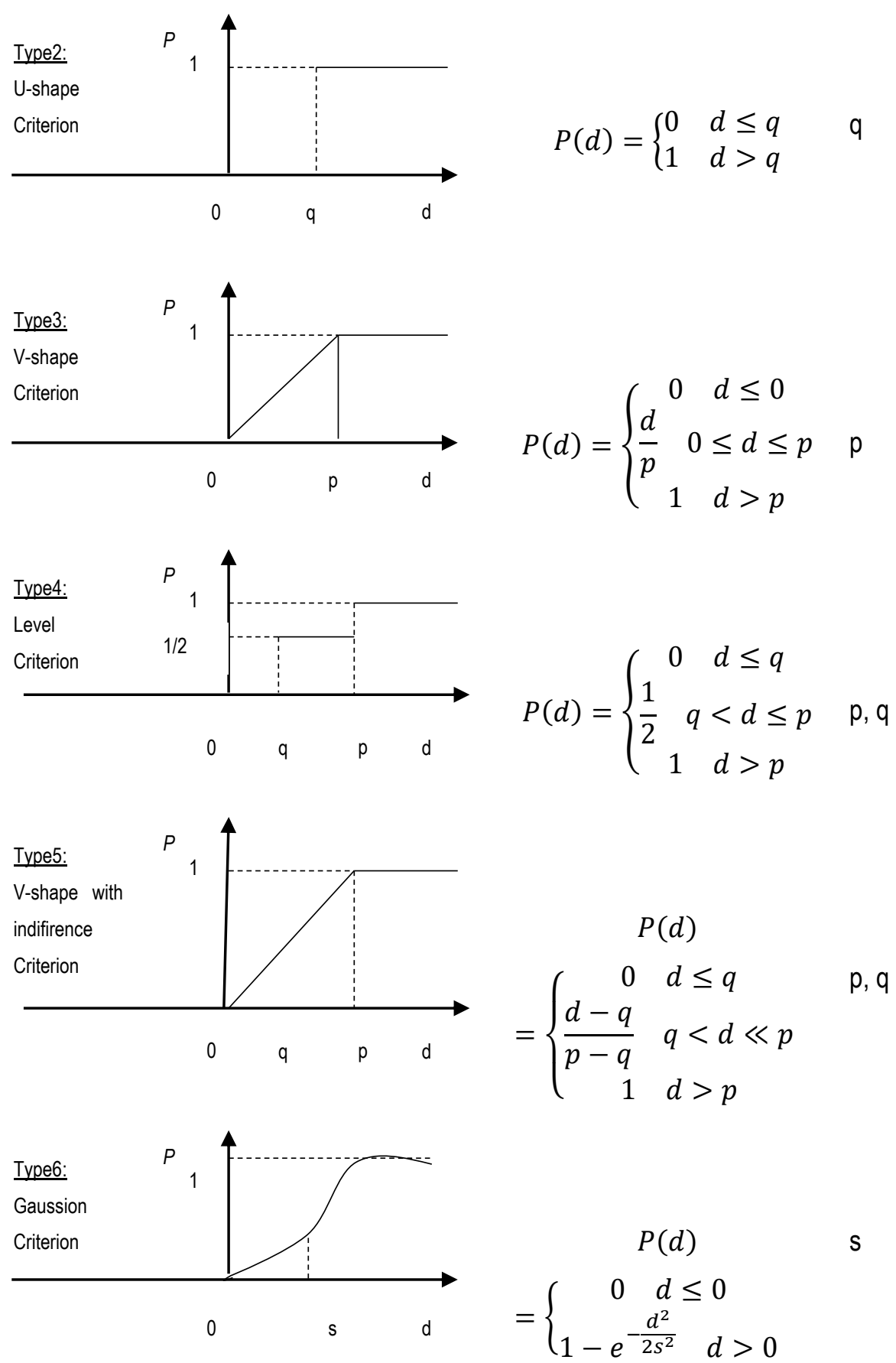

Source: Brans (2005)

The Promethee method is processed through the following steps (Behzadian, 2010; Vujosevic, 2016):

Step 1 . Determination of deviation based on comparison pairs:

$$
d_{j}(a, b)=f_{j}(a)-f_{j}(b), \quad j=1, \ldots, n
$$


where $d_{j}(a, b)$ means the difference between evaluation (grade) $a$ and $b$ according to each criterion.

Step 2 . Apply preference function:

$$
P_{j}(a, b)=F_{j}\left[d_{j}(a, b)\right], \quad j=1, \ldots, n
$$

where $P_{j}(a, b)$ denotes the preference of alternative $a$ in relation to alternative $b$ according to each criterion, as well as in the function $d_{j}(a, b)$.

Step 3. Calculate total or global preference index:

$$
\forall a, b \in A, \quad \pi(a, b)=\sum_{j=1}^{n} P_{j}(a, b) w_{j}
$$

where $\pi(a, b)$ from a over $b$ (from 0 to 1$)$ is defined as the weight $\operatorname{sum} P_{j}(a, b)$ for each criterion, and $w_{j}$ is the weight associated with $j{ }^{\text {th }}$ criterion.

Step 4 . Flow calculation / Promethee and partial ranking:

$$
\emptyset^{+}(a)=\frac{1}{n-1} \sum_{x \in A} \pi(a, x) i \emptyset^{-}(a)=\frac{1}{n-1} \sum_{x \in A} \pi(a, x)
$$

where $\emptyset^{+}(a)$ and $\emptyset^{-}(a)$ denote positive - output flow and negative - input flow for each alternative, respectively.

Step 5. Calculating net flow / Promethee II full ranking:

$$
\varnothing(a)=\emptyset^{+}(a)-\emptyset^{-}(a)
$$

where $\varnothing(a)$ denotes the net flow for each alternative.

The Promethe method ranks alternatives based on the values of positive-output flow $\emptyset^{+}(a)$ and negativeinput flow $\emptyset^{-}(a)$ for each alternative according to (outranking) relations, and in accordance with the assigned weighting coefficients for each criterion.

The positive-output flow of preference shows the extent to which a particular alternative dominates over others. The higher the value of the positive-output flow of a certain alternative, the more significant it is. The negative-input flow of preference shows how much a particular alternative is preferred by other alternatives. The lower the value of the negative-input flow of a certain alternative, the more significant it is.

The final ranking of the alternatives is done on the basis of the value of the net flow $\varnothing(a)$, which represents the difference between the positive-output flow and negative-input flow of the preference. The alternative that has the highest net flow value is the best alternative and so on. 
Radojko, L.

ANALYSIS OF TRADE EFFICIENCY IN SERBIA BASED ON THE PROMETHEE METHOD

\section{EVALUATION OF TRADE EFFICIENCY IN SERBIA USING THE PROMETHHE METHOD}

Table 2 and Figure 1 shows the initial data for measuring the efficiency of trade in Serbia using the Promethee method.

TABLE 2. INITIAL DATA FOR MEASURING THE EFFICIENCY OF TRADE IN SERBIA USING THE PROMETHEE METHOD

\begin{tabular}{|l|l|l|l|l|l|}
\hline & $\begin{array}{l}\text { Employee } \\
\text { earnings }\end{array}$ & Assets & Capital & Sale & Net profit \\
\hline 2013 & 152 & 2160 & 746 & 2891 & 90 \\
\hline 2014 & 155 & 2157 & 761 & 2595 & 87 \\
\hline 2015 & 165 & 2198 & 805 & 2732 & 95 \\
\hline 2016 & 180 & 2325 & 859 & 3010 & 105 \\
\hline 2017 & 195 & 2375 & 921 & 3172 & 125 \\
\hline 2018 & 218 & 2525 & 1011 & 3361 & 122 \\
\hline 2019 & 238 & 2683 & 1073 & 3608 & 139 \\
\hline 2020 & 227 & 2837 & 1183 & 3664 & 171 \\
\hline
\end{tabular}

Note: The data are expressed in billions of dinars

Source: Agency for Business Registers of the Republic of Serbia

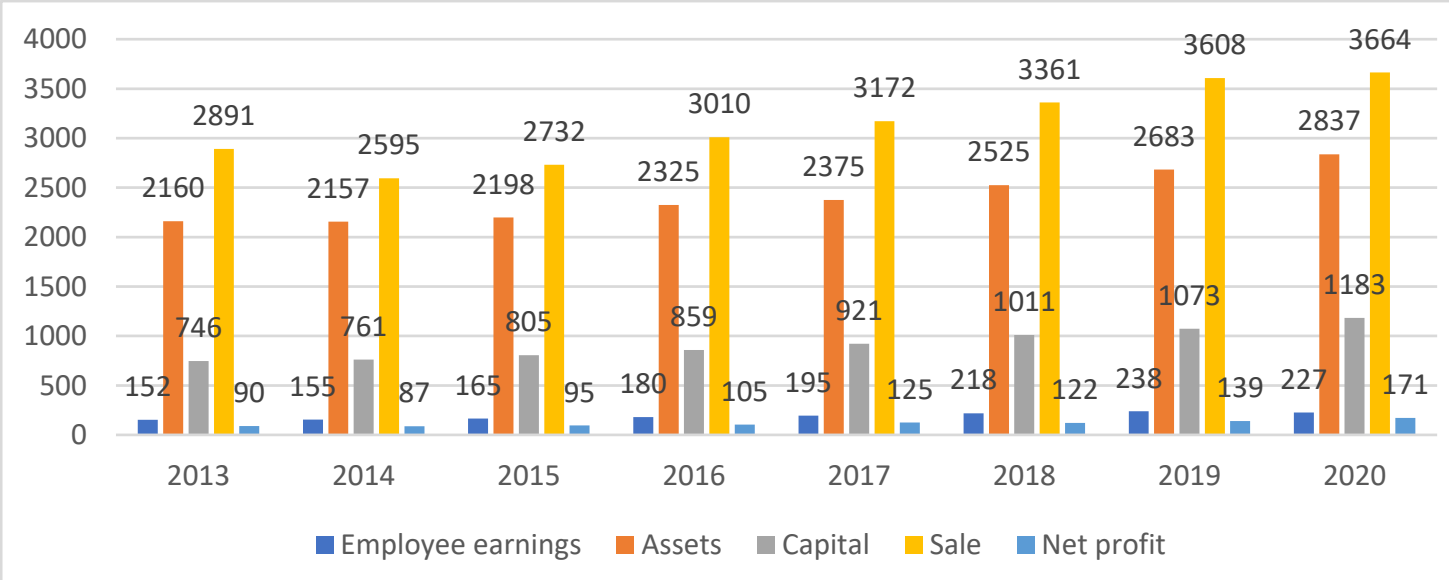

FIGURE 1. DYNAMICS OF EMPLOYEES' EARNINGS, ASSETS, CAPITAL, SALES AND NET PROFIT OF TRADE IN SERBIA

Source: Author's picture

When measuring the efficiency of trade in Serbia on the basis of the Promethee method, C1 - employee earnings, C2 - assets, C3 - capital, C4 - sales and C5 - net profit were taken as criteria, and as alternatives 
analyzed years: A1 - 2013, A2 - 2014, A3 - 2015, A4 - 2016, and A5 - 2017, A6 - 2018 and A7 - 2019 and A8 - 2020. The type of preference function is I - ordinary. Weight coefficients were calculated using the DEMATEL method (Betty Chang, 2011). (The calculation was performed using the Promethee method software, http://ekonom.feld.cvut.cz/vhv-?metoda=8)

Table 3 shows the determination of the function of preferences, appropriate parameters and weight for the needs of measuring the efficiency of trade in Serbia on the basis of the Promethee method.

TABLE 3. PROMETHEE METHOD: DETERMINATION OF PREFERENCE FUNCTION, PARAMETERS AND WEIGHT

\begin{tabular}{|l|l|l|l|l|l|}
\hline \multicolumn{1}{|c|}{$\omega$ 0.2 } & C1 & C2 & C3 & C4 & C5 \\
\hline Type & min & max & max & max & max \\
\hline $\begin{array}{l}\text { Type of } \\
\text { preference } \\
\text { function }\end{array}$ & 1.tip & 1.tip & 1.tip & 1.tip & 1.tip \\
\hline Indifference & & & & & \\
\hline Preference & & & & & \\
\hline 6 & & & & & \\
\hline Weight & 0.207 & 0.161 & 0.186 & 0.224 & 0.222 \\
\hline 2013 & 152 & 2160 & 746 & 2891 & 90 \\
\hline 2014 & 155 & 2157 & 761 & 2595 & 87 \\
\hline 2015 & 165 & 2198 & 805 & 2732 & 95 \\
\hline 2016 & 180 & 2325 & 859 & 3010 & 105 \\
\hline 2017 & 195 & 2375 & 921 & 3172 & 125 \\
\hline 2018 & 218 & 2525 & 1011 & 3361 & 122 \\
\hline 2019 & 238 & 2683 & 1073 & 3608 & 139 \\
\hline 2020 & 227 & 2837 & 1183 & 3664 & 171 \\
\hline
\end{tabular}

Source: Author's calculation

Table 4 and Figure 2 shows the flows ( $\mathrm{F}^{+}$- output, $\mathrm{F}^{-}$- input and $\mathrm{F}$ - net) obtained by applying the Promethee method in the analysis of trade efficiency in Serbia. 
Radojko, L.

ANALYSIS OF TRADE EFFICIENCY IN SERBIA BASED ON THE PROMETHEE METHOD

TABLE 4. PROMETHEE METHOD - FLOWS

\begin{tabular}{|l|l|l|l|l|}
\hline & Option & F + & F- & F \\
\hline 2013 & Option 1 & 0.3257 & 0.6743 & -0.3486 \\
\hline 2014 & Option 2 & 0.204 & 0.796 & -0.592 \\
\hline 2015 & Option 3 & 0.3424 & 0.6576 & -0.3151 \\
\hline 2016 & Option 4 & 0.4581 & 0.5419 & -0.0837 \\
\hline 2017 & Option 5 & 0.5736 & 0.4264 & 0.1471 \\
\hline 2018 & Option 6 & 0.5939 & 0.4061 & 0.1877 \\
\hline 2019 & Option 7 & 0.6797 & 0.3203 & 0.3594 \\
\hline 2020 & Option 8 & 0.8226 & 0.1774 & 0.6451 \\
\hline & Fluxes & & & \\
\hline
\end{tabular}

Source: Author's calculation

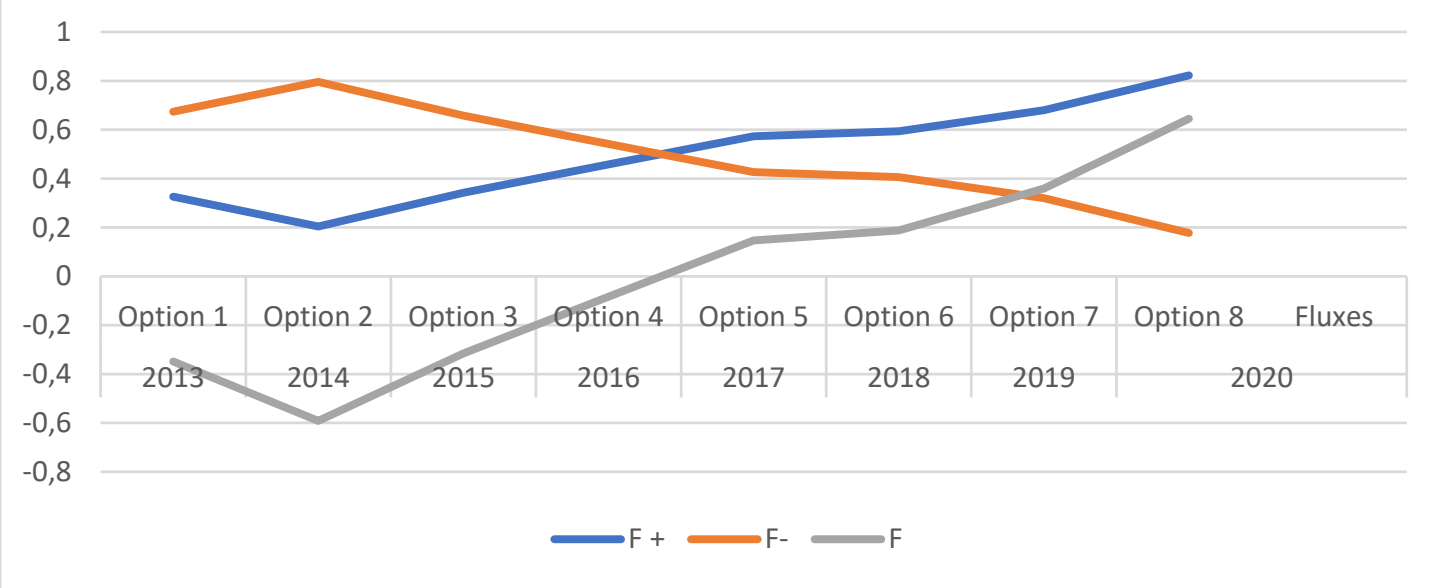

FIGURE 2. FLUXES

Source: Author's picture

Table 5 shows the results obtained (ranking of alternatives) using the Promethee method in the analysis of trade efficiency in Serbia. 
TABLE 5. PROMETHEE METHOD - RESULTS

\begin{tabular}{|c|c|c|c|c|c|c|}
\hline Outcomes & & & & & & \\
\hline Method & Promethe & & Prometh & & Promethee II & \\
\hline Direction & $\downarrow$ & $\uparrow$ & $\downarrow$ & $\uparrow$ & $\downarrow$ & $\uparrow$ \\
\hline 1 & Option 8 & Option 8 & Option 8 & Option 8 & Option 8 & Option 8 \\
\hline 2 & Option 7 & Option 7 & Option 7 & Option 7 & $\begin{array}{l}\text { Option } 5 \\
\text { Option } \\
6 \text { Option } 7\end{array}$ & $\begin{array}{l}\text { Option } 5 \\
\text { Option } \\
6 \text { Option } 7\end{array}$ \\
\hline 3 & Option 6 & Option 6 & Option 6 & Option 6 & Option 4 & Option 4 \\
\hline 4 & Option 5 & Option 5 & Option 5 & Option 5 & $\begin{array}{ll}\text { Option } & 1 \\
\text { Option } 3 & \end{array}$ & $\begin{array}{ll}\text { Option } & 1 \\
\text { Option } 3 & \end{array}$ \\
\hline 5 & Option 4 & Option 4 & Option 4 & Option 4 & Option 2 & Option 2 \\
\hline 6 & Option 3 & Option 3 & Option 3 & Option 3 & & \\
\hline 7 & Option 1 & Option 1 & Option 1 & Option 1 & & \\
\hline 8 & Option 2 & Option 2 & Option 2 & Option 2 & & \\
\hline \multicolumn{7}{|l|}{ Result } \\
\hline
\end{tabular}

Source: Author's calculation

Based on the obtained results of the research on the dynamics of trade efficiency in Serbia using the Promethee method, it can be generally concluded that the efficiency of trade in Serbia increased from year to year in the observed period (2013 - 2020). The best was in 2020. Numerous macro and micro factors have positively contributed to this, such as: favorable general economic conditions, low bank interest rate, stable exchange rate, reduced unemployment rate, increased purchasing power of the population, inflow of foreign direct investment (increasing presence of foreign retail chains in Serbian market), application of new business models (electronic sales, private brand development, sale of organic 
products), application of modern concepts of cost management (calculation of costs by activities, activity management, kaizen concept, value chain management, etc.), product category management, and customer management, as well as the increasing digitalization of the entire business (Ersoy, 2017; Berman, 20218; Levy, 2019; Lukic, 2019; 2020a,b,c) .

The impact of the Covid-19 coronary virus pandemic on trade efficiency in Serbia is negligible. It is, among other things, largely neutralized with the increase in electronic sales. This is the case in other countries as well (Lukic, 2021a,c).

The limited application of the Promethee method in measuring the efficiency of trade in Serbia is reflected in the fact that there are no similar empirical studies in other countries. For the purpose of international comparison, it would be good to measure the efficiency of trade in other countries on the basis of the Promethee method, using the same criteria and alternatives.

Research in this paper has shown that the application of the Promethee method gives accurate results in measuring the efficiency of trade in Serbia. For these reasons, it should be used in parallel with other methods of multi-criteria decision-making (AHP, TOPSIS,GRA, ARAS, and others). Also with ratio and DEA models.

\section{CONCLUSION}

The conducted research of trade efficiency in Serbia on the basis of the Promethee method shows that the continuous efficiency of trade in Serbia increased from year to year in the observed period (2013 2019). The best was in 2019. The key determinants are: favorable general economic conditions, low bank interest rate, stable exchange rate, reduced unemployment rate, increased purchasing power of the population, inflow of foreign direct investment (increasing presence of foreign retail chains in the Serbian market), application of new business models ( electronic sales, private label development, sales of organic products), application of modern cost management concepts (costing by activities, activity management, kaizen concept, value chain management, etc.), product category management, and customer management, as well as increasing digitalization overall business.

The impact of the Covid-19 coronary virus pandemic on trade efficiency in Serbia is negligible. It is, among other things, largely neutralized with the increase in electronic sales. This is the case in other countries as well.

To increase (or maintain the existing) efficiency of trade in Serbia in the future, it is necessary to improve the efficiency of management of human resources, assets, capital, sales, and profits. 
Along with other methods of multi-criteria decision-making, it is recommended, given the importance, simplicity and availability of software, to use the Promethee method in the analysis of trade efficiency using different criteria and alternatives.

\section{REFERENCES}

Behzadian, M., Kazemzadeh, R.B., Albadvi, A., \& Aghdasi, M. (2010). PROMETHEE: A comprehensive literature review on methodologies and applications. European Journal of Operational Research , 200: 198-215.

Berman, B. R., Evans, J. R., Chatterjee, P. M. (2018). Retail Management: A Strategic Approach. $13^{\text {th }}$ Edition, Pearson.

Betty Chang, Chih-Wei Chang, Chih-Hung Wu (2011). Fuzzy DEMATEL method for developing supplier selection criteria, Expert Systems with Applications , 38 (3): 18501858. https://doi.org/10.1016/j.eswa.2010.07.114.

Bölükbaş, U., likelik, E., \& Güneri, A.F. (2012). Performance evaluation of Turkish retail firms using the fuzzy AHP, PROMETHEE, ELECTRE and VIKOR methods. World Scientific Proc. Series on Computer Engineering and Information Science , 7: 243-248.

Brans, J.-P. (1982). Preference Ranking Organization Method for Enrichment Valuations (in French), C300. Vrije University Brussel, 183-213.

Brans, J.P., Mareschal, B. (2005). PROMETHEE methods. In: Figueira, J., Salvatore, G., Ehrgott, M. (Eds.), Multiple Criteria Decision Analysis: State of the Art Surveys. Springer, New York, 163-195.

Brans, J.P., Vincke, P. (1985). A Preference Ranking Organization Method (The Promethee Method for Multiple Criteria Decision Making). Management Sciences , 31 (6): 647-656.

Brans, J.P., Vincke, Ph., Mareschal, B. (1986). How to select and how to rank projects: the PROMETHEE method. European Journal of Operations Research , 24: 228-38.

Ersoy, N. (2017) .Performance measurement in retail industry by using a multi-criteria decision making methods. Ege Acad Rev. , 17 (4): 539-551. https://doi.org/10.21121/eab.2017431302 .

Gaur, L., Agarwal, V., Anshu ,K. (2020). Fuzzy DEMATEL Approach to Identify the Factors Influencing Efficiency of Indian Retail Websites. In: Kapur P., Singh O., Khatri S., Verma A. (eds) Strategic System Assurance and Business Analytics. Asset Analytics (Performance and Safety Management). Springer, Singapore. https://doi.org/10.1007/978-981-15-3647-2_6

Kaushik, V., Khare, A., Boardman, R., \& Cano, M.B. (2020). Why do online retailers succeed? The identification and prioritization of success factors for Indian fashion retailers. Electronic Commerce Research and Applications , 39: 100906.

Kita, P., Furková, A., Reiff, M., Konštiak, P., Sitášová, J. (2017). Impact of Consumer Preferences on Food Chain Choice: An empirical study of consumers in Bratislava. Acta Universitatis Agriculturae et Silviculturae Mendelianae Brunensis , 65 (1): 293-298.

Levy, M., Weitz, B., Grewal, D. (2019). Retailing Management. $10^{\text {th }}$ Edition, Mc Graw Hill.

Lukic, R. and Hadrovic Zekic, B. (2019). Evaluation of efficiency of trade companies in Serbia using the DEA approach. Proceedings of the 19 th International Scientific Conference BUSINESS LOGISTICS IN MODERN MANAGEMENT October 10-11, Osijek, Croatia, Josip Juraj Strossmaye, 145-162.

Lukic, R, Hadrovic Zekic, B. and Crnjac Milic, D. (2020a). Financial performance evaluation of trading companies in Serbia using the integrated Fuzzy AHP - TOPSIS Approach. 9th INTERNATIONAL SCIENTIFIC SYMPOSIUM REGION, ENTREPRENEURSHIP, DEVELOPMENT, Under the 
auspices of: REPUBLIC OF CROATIA MINISTRY OF SCIENCE AND EDUCATION, Osijek, Croatia, Josip Juraj Strossmaye, June, 690-703.

Lukic, R., Vojteski Kljenak, D. and Anđelić, S. (2020b). ANALYZING FINANCIAL PERFORMANCES AND EFFICIENCY OF THE RETAIL FOOD IN SERBIA BY USING THE AHP - TOPSIS METHOD. Economics of Agriculture, 67(1): 55-68), Belgrade.

Lukic, R. (2020C), ANALYSIS OF THE EFFICIENCY OF TRADE IN OIL DERIVATIVES IN SERBIA BY APPLYING THE FUZZY AHP-TOPSIS METHOD, Business Excellence and Management , 10 (3): 80-98.

Lukic, R. (2021a). Application of MABAC Method in Evaluation of Sector Efficiency in Serbia. Review of International Comparative Management , 22 (3): 400-417. DOI: 10.24818 / RMCI.2021.3.400

Lukic, R. (2021b). APPLICATION OF ELECTRE METHOD IN PERFORMANCE ANALYSIS OF FOOD RETAILERS IN SERBIA. Business Excellence and Managemen, 1(3): 84-102. DOI: https://doi.org/10.24818/beman/2021.11.3-05

Lukic, R. (2021c). ANALYSIS OF EFFICIENCY OF TRADE COMPANIES IN SERBIA ON THE BASIS OF SAW METHODS. Economic Views, 23(1): 1-16. (In Serbia: Лукић, Р. (2021). АНАЛИЗА ЕФИКАСНОСТИ ТРГОВИНСКИХ ПРЕДУЗЕЋА У СРБИЈИ НА БАЗИ SАW

Економски погледи, 23(1),1-16)

Okwu, M. O., Tartibu, L. K. (2020). Sustainable supplier selection in the retail industry: A TOPSIS- and ANFIS-based evaluating methodology. International Journal of Engineering Business Management, 12: 1-14. doi:10.1177/1847979019899542

Pachar, N., Darbari, J.D., Govindan, K. et al. (2021). Sustainable performance measurement of Indian retail chain using two-stage network DEA. Ann Oper Res. https://doi.org/10.1007/s10479-021$\underline{04088-y}$

Macharis, C., Springael, J., Brucker, K.D., Verbeke, A. (2004). PROMETHEE and AHP: The design of operational synergies in multicriteria analysis. Strengthening PROMETHEE with ideas of AHP. European Journal of Operational Research , 153: 307-317.

Singh, J., Tyagi, P., Kumar, G. and Agrawal, S. (2020). Convenience store locations prioritization: a fuzzy TOPSIS-GRA hybrid approach. Modern Supply Chain Research and Applications, 2(4): 281302. https://doi.org/10.1108/MSCRA-01-2020-0001

Vujosevic, M., Popovic, M. (2016). The Comparison of the Energy Performance of Hotel Buildings Using PROMETHEE Decision-Making Method. Thermal Science , 20(1): 197-208. 